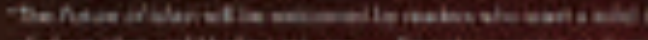

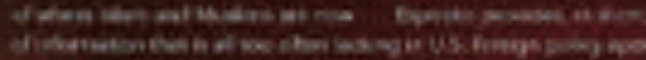

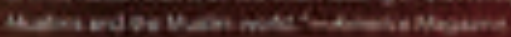

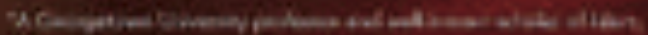

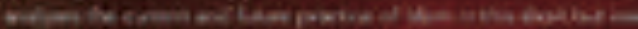

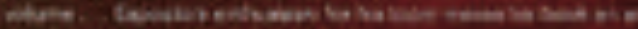

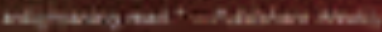

Fi

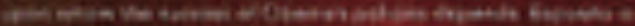

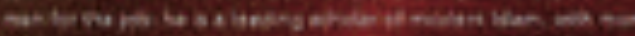

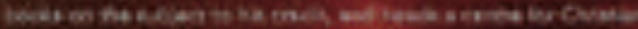

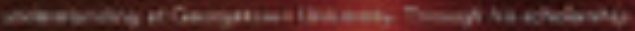

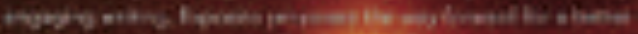

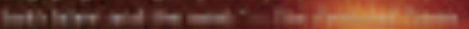

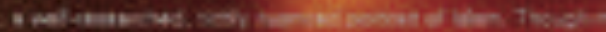

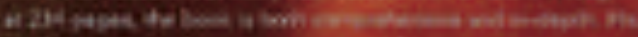

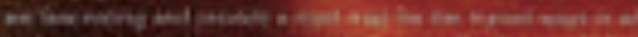

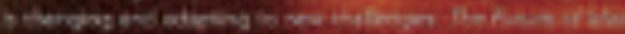

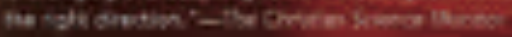

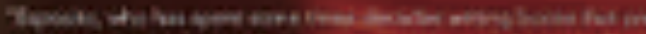

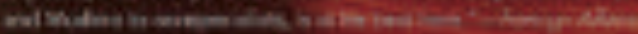

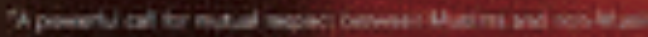

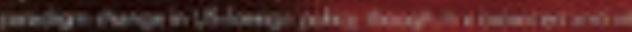

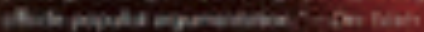

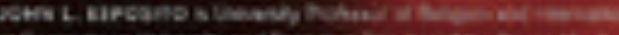

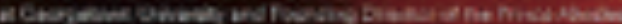

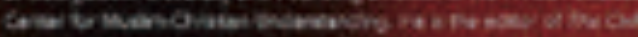

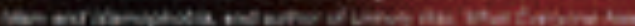

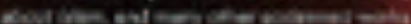

\title{
OXFORD
}

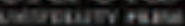

newerse

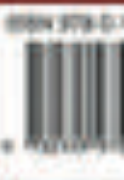

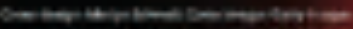

ILUSTRACIJA Portret autora Johna L. Esposita i naslovnica knjige: The Future of Islam. ILLUSTRATION Portrait by John L. Esposito and book cover: The Future of Islam.

Dr. Ahmed Kulanić trenutno radi kao naučni saradnik i koordinator za nauku, istraživanje i obrazovanje u Institutu za bošnjačke studije - BZK Preporod, izvršni je urednik Bosanskih studija - časopisa za istraživanje bosanske misli i kulture. Diplomirao je teologiju na Fakultetu islamskih nauka Univerziteta u Sarajevu, magistrirao na polju političkih znanosti - Odjel za društvene i političke nauke na Internacionalnom univerzitetu u Sarajevu IUS te doktorirao iz oblasti društvenih i političkih znanosti na IUS-u o temi: Religija, ideološke orijentacije i stranačke preferencije Bošnjaka. Radio je kao asistent (2008-2014.), viši asistent (2014-2019) i stručni saradnik (2019.) na Odsjeku za društvene i političke nauke (IUS). U periodu 2011-2014. radio je kao pomoćnik urednika te kao izvršni urednik (2014-2016.) Epiphany - Journal of Transdisciplinary Studies. Dosada je objavio preko 20 naučnih i stručnih radova iz područja islama, političkih nauka i sociologije a koautor je i urednik tri knjige: Bosna $i$ Hercegovina: pravo, društvo i politika, Bosna i Hercegovina i Berlinski proces i Percepcije prema vjerski orijentiranim nevladinim organizacijama, studija slučaja: Bosna i Hercegovina. Učestvovao je na nekoliko istraživačkih projekata u zemlji i svijetu, te bio voditelj projekta „Stavovi, motivi i percepcije kocke i klađenja u Bosni $\mathrm{i}$ Hercegovini“ pod pokroviteljstvom Islamske zajednice u Bosni i Hercegovini. E-mail: ahmedkula@yahoo.com

Dr. Ahmed Kulanić is presently employed as an academic associate and coordinator of science, research and education at the Institute of Bosniak Studies - BZK Preporod. He is also the executive editor of Bosnian Studies - Journal for the research of Bosnian thought and culture. He graduated in theology from the Faculty of Islamic Studies of University of Sarajevo, obtained his master's degree in the area of political studies - Department of Social and Political Studies at the International University of Sarajevo - IUS, and gained his Ph.D. in the area of social and political studies at IUS on the topic: Religion, ideological orientations and party preferences among Bosniaks. He worked as a teaching assistant (2008-2014), senior teaching assistant (2014-2019) and professional associate (2019) at the Department of Social and Political Studies (IUS). In the period 2011-2014 he served as assistant editor, then as executive editor (2014-2016) of Epiphany - Journal of Transdisciplinary Studies. So far, he has published over 20 academic and professional papers in the area of Islam, political studies and sociology, and is the co-author and editor of three books: Bosna i Hercegovina: pravo, društvo i politika (Bosnia and Herzegovina: Law, Society and Politics), Bosna i Hercegovina i Berlinski proces (Bosnia and Herzegovina and the Berlin Process and Percepcije prema vjerski orijentiranim nevladinim organizacijama, studija slučaja: Bosna i Hercegovina (Perceptions of Religion-oriented Nongovernmental Organizations, Case Study: Bosnia and Herzegovina). He has participated in several research projects in his country and internationally, and was the leader of the project "Attitudes, motives and perceptions of gambling and betting in Bosnia and Herzegovina" sponsored by the Islamic Community of Bosnia and Herzegovina. E-Mail: ahmedkula@yahoo.com 
Foreword by Karen Armstrong, ix

Introduction, 3

Chapter I The Many Faces of Islam and Muslims, ro

Chapter 2 God in Politics, 56

Chapter 3 Where Are the Muslim Reformers? 88

Chapter 4 America and the Muslim World: Building a New Way Forward, 142

Conclusion, 195

Notes, 201

Bibliography, 2 I5

Index, 22I

Ahmed KULANIĆ

DOI: $10.52210 /$ sia.v2i1.22

UDK: $28-67(73)$

\section{REFORMA, A NIKAKO REVOLUCIJA}

JOHN L. ESPOSITO, THE FUTURE OF ISLAM, OXFORD UNIVERSITY PRESS, NEW YORK, 2010., xiv + 234, ISBN 978-0-19-516521-0

\section{REFORM, BY NO MEANS REVOLUTION}

JOHN L. ESPOSITO, THE FUTURE OF ISLAM, OXFORD UNIVERSITY PRESS, NEW YORK, 2010, xiv +234 , ISBN 978-0-19-516521-0 


\section{REFORM, BY NO MEANS REVOLUTION}

\section{John L. Esposito, The Future of Islam, Oxford University Press, New York, 2010, xiv + 234, ISBN 978-0-19-516521-0}

$\mathrm{t}$ he many layers and multiplicity of Islam as practiced throughout its history, particularly over the past centuries in the contemporary world, are more than obvious. The complexity of Muslim historical-political development, the challenges and understandings of Islam as a living religion and the search for a system of governance make up the backbone and the basis of Esposito's search for a model for organizing relations between Muslims and the West in his book The Future of Islam, published by Oxford University Press just over ten years ago.

According to the author, the text The Future of Islam was produced as an incentive and attempt to re-build relations between the West and the Muslim world, particularly in the light of the policy of "a new way forward" (p.6) of the then U.S. president Barack Obama, after his 'historic speech' in Cairo - as reported by Western media. The book is concise, and its four basic chapters strive to answer several key questions: What is the future of Islam - reformation or revolution? Are Islam and modernity compatible? How widespread is Islamic fundamentalism and is it a threat to Muslim societies and the West? It also discusses the issue of the compatibility between Islam and modern concepts such as democracy, rule of law, gender equality and human rights and, finally, the issue of Muslims' civil loyalty to American and European states (p. 6).

Esposito begins his book with the chapter "The Many Faces of Islam and Muslims", where he attempts to inform readers on the fundamental characteristics of Islam and Muslims. He speaks of Muslim cultural-historical diversity, Sunni-Shia relations, features of Islam in the West, and Islam-West relations, particularly after the terrorist attacks in the USA, England, Spain and Scotland, and demystifies Huntington's thesis on the conflict of civilizations and irreconcilable differences. In his efforts, Esposi- to advocates the thesis of the need to focus on the attitudes of the silent majority of Muslims and their views on a broad spectrum of contemporary topics and issues. He finds evidence for their views in Gallup and Pew Center research.

The search for identity is one of the crucial issues facing Muslims in the West. One could claim that it is one of the key rifts and challenges imposed on Muslims in the West - a false dilemma which is reflected in the creation of the construct of being a "Muslim in the West" or a "Western Muslim", i.e. in the issue of preserving identity in the processes of integration or assimilation, or the capability and possibility of political pluralism of the West (p. 23). The second issue, perhaps a more important one in the context of Europe, is the implementation of anti-immigrant policy and the overemphasis on the collapse of the European cultural-religious framework and the concept of European values in the media (p. 26), which largely contributed to the spreading of anti-Islamic and anti-Muslim sentiment, and to the emergence and unstoppable spread of Islamophobia in Europe. The author sees the solution or the direction/road that the West has to take in identifying the key issues or answers to the question "What do Muslims really want?" and offers a starting point in the key findings of Gallup and the Pew Research Center on the views of most Muslims in the West. This basis implies improvement of economic conditions, employment possibilities, improvement of living standards, strengthening the rule of law and democratic principles, and elimination of social tensions (p. 55) - which actually suggests that Muslims (in the West) and their views on socio-economic organization do not differ much from those of their fellow citizens.

The second chapter, "God in Politics" provides an insight into the historical context of religion in politics and society, and in the emergence of what is 
now called "political Islam". Striving to present the entire diversity of the political scene and thought in Muslim countries, Esposito identifies and describes the presence of both fully democratic and extreme political ideologies and the parties in them. The emergence of fundamentalist movements and interpretations is nothing new; indeed, they are the response, through some policies, to challenges faced by contemporary societies both in the East and in the West. In this context, Esposito describes the example of US president Ronald Reagan, who resorted to reviving and retrieving the principles and values of the founders of the United States of America, i.e. to the restoration of its foundations with the aim of recovering the failed American foreign policy of the 1970 s (p. 60). Religious awakening is not, in its essence, exclusively religious; rather, it is a response to economic, political and social decline and, ultimately, to the loss of identity, as well as a basis for searching and responding through romanticized history and a return to the "ideal" times of the emergence and establishment of states and civilizations, both in the West and among Muslims.

The basic premise of the strengthening of fundamental movements in Muslim countries is reflected in their emergence as a response to US foreign policy towards these countries in the last century, a policy that focuses on the process of strengthening authoritarian regimes in Muslim countries. From the mid-1970s to the early 1990s, Muslim extremist groups mostly focused their activities within their own countries, while the mid-1990s saw the beginning of "export" (p. 77) and their global activity, which would reach a climax in the attack of 11 September 2001. The policy of conflict, which has been particularly evident in the relations between the USA and the Muslim world after 11 September, does not offer (adequate) solutions for contemporary challenges; on the contrary, it deepens the gap between them. Overcoming this gap is reflected in the strengthening of reform processes among Muslims, both in religion and policy, aimed at marginalizing and containing the influence of religious extremist and terrorist groups and their leaders. In this respect, encour- aging and publicly advocating coexistence by most Muslims and their religious leaders and intellectuals is a way out of the described decline.

Islam has certainly become the dominant force of Muslim politics. Therefore, its basic task is to formulate and implement doctrinal and educational reforms which will more efficiently respond to the contemporary challenges of $21^{\text {st }}$ century globalization and, in cooperation with other religious traditions, commit itself to an inclusive, rather than exclusive, understanding of theologies (p. 87).

Esposito claims in the beginning of the third chapter, "Islam Needs a Reformation", that the key issue for the future of Islam and Muslims, as well as for the struggle against terrorism in the $21^{\text {st }}$ century, is the issue of Islamic reform. For Esposito, questions as to whether Islam is capable of reform and whether there are Islamic reformers are meaningless and absurd (pp. 88-89). Indeed, the crucial issues are how much and what kind of reforms are needed and necessary. In this respect, the chapter presents the views and reasoning of thinkers such as Tariq Ramadan, Amr Khaled, Sheikh Ali Goma'a, Mustafa Cerić, Yusuf al-Qaradawi, Nurcholish Madjid, Timothy Winter, Farhat Hashemi, Amina Wadud, Heba Raouf and Abdullah Gymnastiar. For Esposito, they make up the backbone of Muslim reformers at the present time. While the listed authors question and deal with the role of Islam in the contemporary world, their key task remains "linking, showing continuity, between the proposed changes and long-held Islamic beliefs and traditions" (p. 94). Potential strength as well as the desire for religious, political, and even social reform can be found among the (moderate) Muslim majority (pp. 139-140), while Muslims in the West are essentially a source and signpost to widely desired reforms. The practice of demonizing and discriminating against Muslims undermines the development of the multi-religious social mosaic in the West (p. 141), while synergy in confronting extremist ideologies and movements is one of the basic tasks both of the West and of Muslims.

In the fourth chapter, Esposito analyzes and contextualizes the relationship of US foreign policy to- 
ward the Muslim world, particularly in the light of increased Islamophobia and the role of the media. He sets out to search for the "missing link" between the USA and the Muslim world during George Bush's term of office. In this respect, the author particularly emphasizes the role of interfaith dialogue and interfaith initiatives such as the "Amman Message" (pp. 186-187) and "A Common Word" - which he believes to be a "new chapter in a long history" (p. 189). In the conclusion of the chapter, Esposito calls for resuming trust among participants, greater tolerance as well as a deeper analysis of what is actually advocated by most Muslims, rather than by radical groups which have occupied the public space and opinion, and ends with President Obama's words that "America and Islam are not exclusive and need not be in competition." (p. 194).

There are several key issues that the book The Future of Islam puts forward and considers as challenges in relations between Muslims and the West. Above all, it is the creation and establishment of the "missing link" by introducing the concept of the common Judeo-Christian-Islamic heritage in the public discourse, since the three religions have had a shared history (p. 198). Secondly, the fundamental problem for relations between the West and Muslims and for the development of long-term stability is not Islam but the authoritarian regimes and the lack of (political) pluralism within them. Contemporary Muslims stand at a major crossroads in their history and therefore encouraging and focusing on the voices of modern Muslim reformers should be the primary focus of Western politics in order to work jointly on articulating a "progressive and constructive Islamic framework" to deal with modernization and development, democratization and pluralism. The future of global civilization and our role is reflected in finding ways and solutions for working together to establish the rule of law, and freedom of religion, speech and assembly for overall economic and educational advancement.

Reading The Future of Islam from a decade-long time distance entitles me to give a short review of its significance. All the dilemmas, challenges and problems related to the Muslim world that Esposito identified and presented in The Future of Islam are only too present even today. The hopes that Muslims pinned on Barack Obama in the beginning of his eight year-long term of office were dashed and had almost disappeared by its end, and were particularly complicated during the term of office of his successor. The process of democratization and the revolutionary attempt to depose authoritarian regimes in the Muslim world experienced a fiasco, which actually confirmed the basic thesis of The Future of Islam - that Muslims need reformation, rather than revolution. Even today, ten years after The Future of Islam was produced, it seems to me that Muslims search for and need their "Martin Luther" even more than in the early $21^{\text {st }}$ century. With respect to the West, a different approach and reasoning can hardly be expected, particularly due to the image of Muslims, which has to a large extent been constructed by the extremist Muslim minority and by the strengthening of the populist and rightist movements in the West, whose basic ideology focuses on Muslims and anti-immigrant policy. The voices of most Muslims remain insufficiently loud in the Western world, which is searching for a new "other and different" - both in Europe and in the USA. I am afraid of the hopes pinned on the newly elected US president being dashed once again.

Finally, Esposito's favorable view of Bosnian Muslims and the Islamic community in Bosnia and Herzegovina in the context of the regulation of relations between the state and religion, coexistence, tolerance and pluralism is what draws particular attention to this, unfortunately untranslated text. 